Edward STAWASZ, PhD, Professor of the University of Lodz

Faculty of Management, University of Lodz

e-mail: edward.stawasz@uni.lodz.pl

ORCID: 0000-0003-4744-6096

DOI: $10.15290 /$ oes.2021.02.104.01

\title{
BUSINESS KNOWLEDGE ABSORPTIVE CAPACITY IN MICRO AND SMALL INNOVATIVE ENTERPRISES ${ }^{1}$
}

\begin{abstract}
Summary
Purpose - The aim of the presented article is to assess the impact of the capacity to absorb business advice on the improvement of business knowledge, and indirectly, on raising the level of strategic and operational management in micro and small innovative enterprises using business advice services.

Research method - A review of the literature on examining the specificity of knowledge and management development in enterprises, the role of business advice and the capacity to absorb knowledge in this process. The second part of the article presents the results of the empirical research carried out using the CATI technique on a sample of 400 micro and small innovative Polish enterprises using business advice services.

Results - The use of business advice services and the level of knowledge absorptive capacity increase the level of business knowledge of managers. The capacity to absorb knowledge positively moderates the impact of business advice on the level of business knowledge of managers, and, consequently, on the level of strategic and operational management.

Originality / value - The research confirms the influence of the capacity to absorb knowledge on the level of knowledge of managers. Improving the level of knowledge and business management requires the use of business advice as well as the capacity to absorb knowledge.
\end{abstract}

Keywords: micro and small business, knowledge absorptive capacity, business advice

JEL Classification: D25, L25

\section{Introduction}

In the literature devoted to management in the sector of micro and small enterprises, the low level of knowledge, including management knowledge, is mentioned as a barrier to running enterprises successfully in an increasingly uncertain environment. The necessary knowledge can be developed independently by entrepreneurs/ managers as well as obtained from the environment, from advisors, in the form of a professional and independent service, and it can influence the creation of develop-

1 Article received on 6 February 2021, accepted on 9 March 2021. 
mental orientation which can be expressed by formulating the strategy of enterprise development [Blackburn et al., 2013].

The use of business knowledge obtained from advisors to improve the level of knowledge and management poses numerous challenges for micro and small enterprises. These challenges are particularly significant given that these enterprises usually do not have an appropriate management structure or professional managers. An important role in this respect can be played by the capacity to absorb business knowledge, including the ability to recognise the value of new knowledge, to assimilate and transform it into a commercial outcome [Grabowski, Stawasz, 2017; Zahra, George, 2002]. This issue is relatively poorly recognised in the literature [Duchek, 2015]. Therefore, it may be interesting to examine the importance of the capacity to absorb business knowledge in shaping the level of business knowledge and management of enterprises.

The aim of the presented article is the assessment of the role and determinants of business knowledge absorptive capacity in shaping the level of business knowledge and management of micro and small innovative enterprises in the context of using business advice services. It discusses the specificity of management and creation of knowledge in enterprises, the role of business advice and the capacity to absorb knowledge in this process. The second part of the paper presents the results of the empirical research carried out using the CATI method on a sample of 400 Polish micro and small innovative enterprises. ${ }^{2}$

\section{Literature review}

The specific features of small businesses, in particular of the smallest scale entities, include primarily the dominant role of the owner in managing the entity, simple structures, limited tangible and intangible resources, and an intuitive way of managing. Key decisions regarding the enterprise are usually taken by one person the owner. His or her personal characteristics and attitudes, knowledge, experience and skills determine the way of managing the company and the probability of its success or failure. In line with the resource-based approach, limited resources, including knowledge and management capabilities, can be an obstacle to creating a lasting competitive advantage for smaller enterprises [Teece, 2014; Dyer, Ross, 2007].

An important problem for these enterprises is access to data, and their further proper analysis, in particular the lack of time for the in-depth analysis, the incorrect interpretation of signals and limited financial resources [Lisowska, 2015]. This causes dependence of small entities on external sources of knowledge to a much higher degree compared to larger organisations, which results, on one hand, from

2 The publication was created as a result of the project of the National Science Centre entitled "Shaping the Competitiveness of a Small Company - the Role of Business Advice" (No. UMO-2012/07/B/ HS4/03019). 
a limited organisational internal knowledge base, and, on the other hand, from far greater possibilities of transferring knowledge within the framework of direct interactions [Hutchinson, Quintas, 2008]. The capacity of enterprises to use and absorb external support can, therefore, be a factor conducive to the improvement of management quality and their developmental orientation [Sciascia et al., 2014].

Business knowledge is characterized by its wide scope, enabling the company to understand the needs of resource management and to plan and implement processes allowing its operation and development in the market conditions. The basic areas of business knowledge important at the stage of enterprise creation include marketing, planning and management of processes, human resources and financial management. The importance of the level of various business knowledge components in the company for its achieved business results has been pointed out [Krzakiewicz, Cyfert, 2018; Mazzarol, 2011, p. 161-162].

Many sources of business knowledge in a small entity are external, related to the transfer of knowledge from institutions and people in the company's environment. This group includes various types of institutions operating in the area of training and education, business advisors, as well as business partners cooperating with small business in various configurations. In the case of small entities and their business knowledge base, some weaknesses of this source of knowledge are visible, especially in relation to the dominant position of the entrepreneur within the company management structure. However, they mainly concern the transfer of knowledge in the field of strategic management, which is the exclusive domain (and competence) of the entrepreneur [Stawasz et al., 2018, p. 56-57]. Striving for independence may in some cases limit the tendency to use external sources of business knowledge. Owners/managers essentially seek external knowledge which can be directly applied in implemented processes.

Business advice is one of the elements of the external support for micro and small enterprises. Its aim is to help managers and enterprises achieve their goals by: solving problems in the sphere of management, identifying and making use of new opportunities, learning and implementing changes [Yusoff et al, 2010]. It involves the transfer of business information, both in terms of day-to-day and strategic management [Blackburn et al., 2013], serving as a potential source of competitive advantage [Gooderham et al., 2004].

Advisory services are provided by professional consultants from the public or commercial sector, taking on various forms, ranging from sharing general knowledge, through specialised training to coaching and mentoring [Mole et al., 2013]. The sources of business advice are usually accountants, suppliers, bank employees, customers or other business partners.

Among the benefits of business advice, a direct and indirect impact can be distinguished. The direct impact concerns the provision of strategic advice for the improvement of innovativeness, growth and development of the company. Intermediary actions, on the other hand, include business support in terms of solutions and procedures aimed at increasing the amount of managers' knowledge, experience and application of management practices useful for strategic management as 
well as supporting the relationship between managers' knowledge and formulating development strategies [Głodek et al., 2016].

The use of business advice is generally stimulated by the gap between the internal resources of business knowledge and the resources necessary to achieve business objectives [Carey, 2015]. It seems to be particularly important for innovative companies, especially when their competitive situation is perceived in terms of dependence on the possibility of effective access to knowledge resources [Kang, Kang, 2009]. It is indicated that the use of business advice is diversified due to the specificity of business activity, market, technology, sector or geographic location [Blackburn et al., 2013; Mole et al., 2013]. Factors that can determine the use of advisory services should also include factors characterising the manager (education and experience), factors related to the company (scale of activity, age), and factors related to its developmental orientation (a development strategy in place or lack thereof) [Zou et al., 2018].

To assess the role of business advice in the functioning of micro and small enterprises, the concept of knowledge absorptive capacity may be useful. In the management literature, the capacity to absorb knowledge is defined as the ability of enterprises to recognise the value of new knowledge, to assimilate and transform it into a commercial outcome [Zahra, George, 2002]. It is a dynamic ability, acting as a moderator, which can influence the performance of enterprises in a dynamic environment by supporting, among others, an increase in the level of managers' business knowledge as well as the improvement in the level of management and the innovation process [Matejun, 2015, p. 80-81; Engelen et al., 2014].

The acquisition and use of external business knowledge by micro and small enterprises to improve their performance poses challenges in terms of building their absorptive capacity, all the more given the fact that they usually do not have an appropriate management structure or professional managers (this applies in particular to microenterprises). An important role in this area is played by the ability to recognise the value of advisory information offered and the ability to assimilate it, allowing analysis, interpretation and understanding [Raymond et al., 2015]. These abilities are particularly important and difficult to obtain in technologically advanced and innovative industries [Patterson, Ambrosini, 2015]. The ability to transform information implies the ability to change and develop procedures that allow for integrating the existing knowledge with advisory knowledge, expanding knowledge, modifying it, and achieving synergy. In turn, the ability to make use of this knowledge resource means the opportunity to improve the existing or to create new management competences (including creating development strategies or developing innovations).

The relationships between the capacity to absorb business knowledge, the level of business knowledge and management effects in the context of using business advice seem to be important for the functioning of micro and small enterprises [Lagunes et al., 2017; Daspit, D'Souza, 2013]. Strong dependencies mean that the capacity to absorb knowledge seems to be a prerequisite for the effectiveness of using business advice services aimed at increasing managers' knowledge [Adomako 
et.al., 2016]. Business managers' greater knowledge has a positive impact on improving the level of management, which may result in improved company performance (growth, competitiveness, innovativeness, profitability).

\section{Proposed impact model}

CHART 1

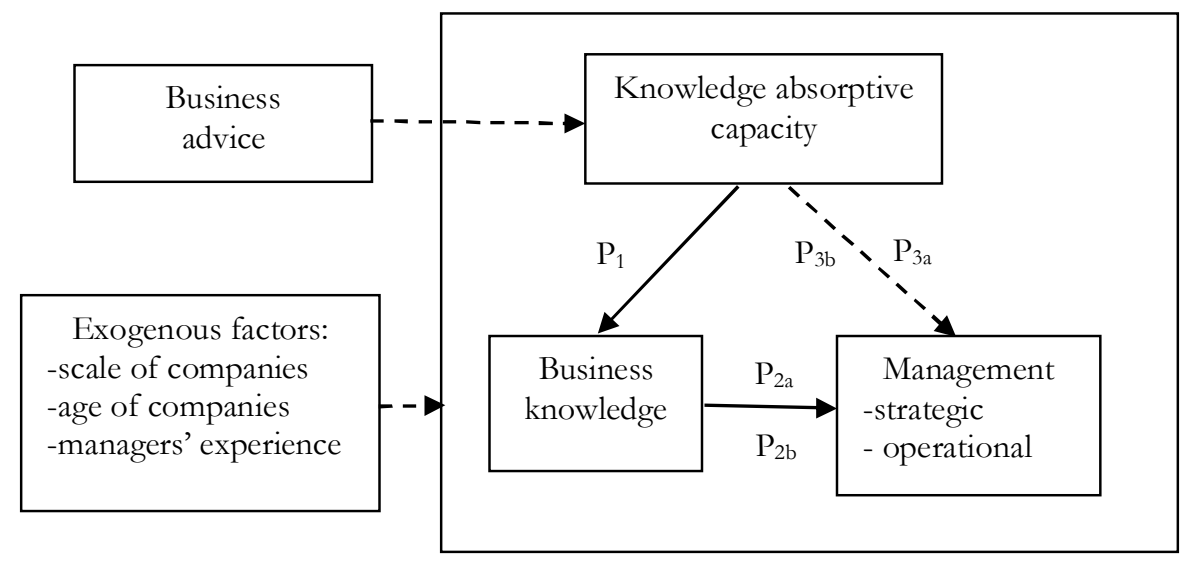

Source: own elaboration.

The dependency model is presented in chart 1 . The following three impacts were distinguished: the impact of the capacity to absorb knowledge on the level of business knowledge of managers $\left(\mathrm{P}_{1}\right)$, the impact of business knowledge on the level of strategic management $\left(\mathrm{P}_{2 \mathrm{~b}}\right)$, as well as the indirect impact of knowledge absorptive capacity on the level of strategic management $\left(\mathrm{P}_{3 a}\right)$ and operational management $\left(\mathrm{P}_{3 \mathrm{~b}}\right)$. Selected factors related to the company and the personal characteristics of the manager are treated as the so-called exogenous factors (the age and scale of companies, managers' experience).

\section{Characteristics of the sample}

The article uses the database of 400 micro and small-sized enterprises operating in the country, meeting the criterion of innovativeness, and at the same time using external business advice services in the last three years before the interview (20142016). The original data obtained as a result of the surveys were subjected to statistical analysis and comparative statistical analysis. The selection of factors determining the impact of business advice on selected areas of operation and performance of small innovative companies was carried out taking into account the following criteria: substantive, formal and statistical ones.

In the market structure of the 400 companies surveyed, the local and domestic market predominated $(37.5 \%$ and $45.5 \%$ respectively), while entities with the domi- 
nant international market accounted for $16.8 \%$ of the total sample. The majority of the surveyed companies were mature enterprises with a 4-10 year market presence (49.8\% of the sample), while the average employment was 7.7 people. The industry structure of the sample was very diverse: services predominated $(74.8 \%$ of enterprises), followed by enterprises from the IT industry (22.3\%), trade $(15.5 \%$ of enterprises) and manufacturing companies (9.8\% of enterprises).

The analysed population consisted of one-person-managed companies $(60 \%$ of entities), followed by two-person-managed companies (approx. $28 \%$ of companies). $12.3 \%$ of the surveyed enterprises had the management consisting of three or more people. Half of the managers had technical and scientific educational background, followed by economic education (31\%). Business managers were characterised by extensive professional experience, as evidenced by the average working age of managers, which was high and amounted to 12.6 years.

In the years 2014-2016, all the surveyed enterprises used business advisory services related to their business operations. The basic areas of services provided included sources of financing and accounting (39.3\% of entities), followed by legal and tax services (18.5\% of companies), production, logistics and IT $(12.5 \%$ of enterprises), as well as strategic and development management (10.5\% of companies). The motives of using business advice services included a gap in the surveyed managers' business knowledge and problems in company management. Nearly 59\% of enterprises using business advisory services claimed that they had obtained benefits as expected, and 35\% of enterprises had obtained benefits partly in line with expectations. Only $6 \%$ of entities stated that the consultancy results obtained had not been in line with their expectations.

\section{Results of empirical research}

\subsection{Business advice knowledge absorptive capacity}

The analysis assessed the skills of the surveyed managers regarding the absorption of knowledge obtained from business advisors on a scale of 1-5 points. The average assessment of the total absorptive capacity was quite high (3.6 points). High assessments of the managers concerning the capacity of their companies to absorb knowledge obtained from business advisors were related to many features of their enterprises. These provided ratings were higher in the case of more innovative, competitive, pro-developmental companies using formal planning procedures, as well as in the case of higher assessment of management knowledge, a more frequent use of business advice services, including professional consulting services, and learning from professional advisors.

The average ratings for the five areas of business advice knowledge absorptive capacity were quite high and oscillated in the range of 3.5-3.8 points. The highest scores were recorded in the case of assimilation of knowledge (3.8 points) and its practical application (3.6 points). Slightly lower ratings (though also noticeable) were 
obtained for managerial skills in other areas, i.e. the recognition of the value of knowledge (3.5 points) and its acquisition and transformation (3.5 points).

\subsection{Business knowledge}

The self-assessment of the surveyed managers' knowledge on the 1-5 point Likert-type scale, where 1 meant a very low level of knowledge and 5 meant a very high level of knowledge, was chosen as the measure of the managers' knowledge level. This assessment concerned the surveyed managers' opinions on the state of their current knowledge in the field of managing the company in its various areas, including management techniques and methods. The average level of business knowledge in the studied population was quite high and amounted to 3.81 points.

There is a clear dependency of the assessment of business knowledge related to: the scale of operations of entities, their competitiveness and innovativeness, the existence of a formal development plan, the age of companies, as well as the experience and education of their managers.

Learning on the basis of personal experience (over $2 / 3$ of companies) is one of the basic sources of improving managers' business knowledge. The other sources are less important. Learning from business partners is signalled by $15.5 \%$ of companies, courses and training sessions by $9 \%$ of companies. The use of business advice services concerns $7.5 \%$ of companies. Taking into account multiple responses, over $3 / 4$ companies use learning based on their own experience, approx. $40 \%$ learn from business partners as well as courses and training. However, $1 / 4$ of companies use professional business advice services as a source of knowledge.

\subsection{Management level}

As a criterion for the assessment of the level of management in the surveyed companies, the estimation of the total self-assessment index taking the values on the Likert scale from 1 to 5 points was adopted in two selected areas (strategic management, day-to-day management), where 1 meant a very low level of management knowledge, and 5 - a very high level of management knowledge. The average assessment of the total management level was high and amounted to 3.91 points. It proved high self-assessment of managerial skills. A very low management level was reported by $1.0 \%$ of the managers surveyed and very high by $31.8 \%$. The level of day-to-day management was rated higher - the average rating was 4.1 points, compared to the level of strategic management (company development management) - the average rating was 3.8 points.

\subsection{Dependencies}

In order to establish interdependencies between the absorptive capacity of business knowledge, the level of business knowledge of managers and the level of management in the context of business advice, Pearson's correlation coefficient was applied (table 1). The conducted analysis shows that the capacity to absorb knowledge affects the level of knowledge of managers and the level of management. 
The dependencies of these variables are statistically significant. The correlation coefficient of knowledge absorptive capacity and raising the level of managers' business knowledge is moderate (0.315), with a level of significance of 0.01 . This indicates a positive impact of the capacity to absorb knowledge on increasing the level of business knowledge of managers $\left(\mathrm{P}_{1}\right)$. Increasing the level of business knowledge is correlated with the improvement of the level of strategic and operational management - the correlation coefficient is high and amounts to: 0.438 and 0.437 respectively, at a level of significance of 0.01 , which may mean that the greater the improvement of the level of business knowledge obtained as a result of using business advice, the higher the improvement of the level of strategic management $\left(\mathrm{P}_{2 a}\right)$ and operational management $\left(\mathrm{P}_{2 b}\right)$. The correlation coefficient of knowledge absorptive capacity and the improvement of the level of strategic management and operational management is moderate, and amounts to: 0.280 and 0.207 respectively, at a level of significance of 0.01. It may mean that the higher the capacity to absorb knowledge, the greater the improvement of the level of business knowledge of managers and the greater the improvement of the level of strategic management $\left(\mathrm{P}_{3 a}\right)$ and operational management $\left(\mathrm{P}_{3 a}\right)$ in micro and small enterprises.

TABLE 1

\section{Dependencies}

\begin{tabular}{|l|l|c|c|c|c|c|c|c|}
\hline & & $\mathbf{1}$ & $\mathbf{2}$ & $\mathbf{3}$ & $\mathbf{4}$ & $\mathbf{5}$ & $\mathbf{6}$ & $\mathbf{7}$ \\
\hline 1 & KAC & 1.000 & & & & & & \\
\hline 2 & IMK & $0.351^{* *}$ & 1.000 & & & & & \\
\hline 3 & ILSM & $0.280^{* *}$ & $0.438^{* *}$ & 1.000 & & & & \\
\hline 4 & ILOP & $0.207^{* *}$ & $0.437^{* *}$ & $0.713^{* *}$ & 1.000 & & & \\
\hline 5 & SCALE & 0.032 & $-0.185^{* *}$ & -0.005 & -0.032 & 1.000 & & \\
\hline 6 & AGE & $0.119^{* *}$ & 0.077 & 0.071 & 0.071 & 0.081 & 1.000 & \\
\hline 7 & EXP & $0.133^{*}$ & 0.073 & $0.129^{* *}$ & $0.108^{*}$ & $0.237^{* *}$ & $0.444^{* *}$ & 1.000 \\
\hline
\end{tabular}

${ }^{* *}$ significance level $<0.01$; ${ }^{*}$ significance level $<0.05$; KAC - business knowledge absorptive capacity; IMK- improvement in managers' level of knowledge; ILSM - improvement of the level of strategic management; ILOP - improvement of the level of operational management; SCALE - scale of companies; AGE - age of companies; EXP - managers' experience.

Source: own elaboration.

The analysis revealed a statistically significant, though moderate, relationship between the absorptive capacity of business advice knowledge and the experience of managers (correlation coefficient is 0.133 ) along with the age of enterprises (the correlation coefficient is 0.119). It can, therefore, be concluded that the older the enterprise and the more experienced the managers, the greater the positive impact on increasing the knowledge absorptive capacity in enterprises. However, the impact of the scale of enterprises on the capacity to absorb business knowledge has not been observed. 
In order to check whether the capacity to absorb business knowledge is a stimulus to improve the level of business knowledge of managers, the level of strategic management and operational management, the parameters of the following polychotomic models of ordered categories have been additionally estimated:

$$
\begin{gathered}
D V_{i}^{*}=\alpha K A C_{i}+\varepsilon_{i}, \\
D V_{i}=2 \text { when } D V_{i}^{*}>\mu_{2}, \\
D V_{i}=1 \text { when } \mu_{1}<D V_{i}^{*} \leq \mu_{2}, \\
D V_{i}=0 \text { when } D V_{i}^{*} \leq \mu_{1}
\end{gathered}
$$

where denotes the summary value of knowledge absorptive capacity, while is a dependent variable related to the improvement of the level of business knowledge as a result of the use of business advice services, the improvement of the level of strategic management and the improvement of the level of operational management as a result of business advice obtained. It takes on the three following values:

0 - if the respondent indicates a value of 1 or 2 ,

1 - if the respondent indicates a value of 3 ,

2 - if the respondent indicates a value of 4 or 5 .

Table 2 presents the results of the estimation of the parameters of the ordered probit model for all three variants:

TABLE 2

The results of the estimation of the parameters of the ordered probit model

\begin{tabular}{|c|c|c|c|}
\hline \multirow{2}{*}{ KAC } & Knowledge equation & $\begin{array}{c}\text { Strategic management } \\
\text { equation }\end{array}$ & $\begin{array}{c}\text { Operational } \\
\text { management equation }\end{array}$ \\
\cline { 2 - 4 } & $0.429^{* * *}$ & $0.379^{* * *}$ & $0.328^{* * *}$ \\
\cline { 2 - 4 } & 0.819 & 1.031 & 0.940 \\
\hline
\end{tabular}

${ }^{* * *}$ significance level $<0.01$.

Source: own elaboration.

In each of the above-presented equations, the capacity to absorb business knowledge significantly changes the probability that the dependent variable will take the highest value. It means that the capacity to absorb knowledge stimulates the impact of business advice on the level of business knowledge of managers, and, consequently, on the level of strategic and operational management. 


\section{Conclusions}

Business advice is one of the sources of increasing the level of business knowledge of managers as well as the level of management in micro and small innovative enterprises. The capacity to absorb knowledge as a prerequisite of using business advice services, improving the knowledge level of managers, and raising the level of business management plays an important role.

The conducted analysis of the research results confirms the existence of the relationships between the capacity to absorb knowledge, the level of business knowledge of managers and the level of business management. The use of business advice services and the level of knowledge absorptive capacity increase the level of business knowledge of managers and can be considered as effective factors in improving the level of management. The greater the capacity to absorb knowledge, the greater the improvement of business managers' knowledge in enterprises. A higher level of capacity to absorb knowledge positively influences the level of strategic and operational management. Similarly, improving the level of business knowledge obtained as a result of the use of business advice has also a positive impact on the improvement of the level of strategic and operational management. Therefore, it can be concluded that the capacity to absorb knowledge positively moderates the impact of business advice on the level of business knowledge of managers, and, consequently, on the level of strategic and operational management.

The characteristics that may affect the knowledge absorptive capacity include factors related to both companies and managers. The age of companies and their managers' experience have a positive impact on increasing the knowledge absorptive capacity of micro and small enterprises. The older the enterprise and the more experienced the managers, the greater the impact on increasing the knowledge absorptive capacity. However, the impact of the scale of companies on the capacity to absorb knowledge has not been observed.

\section{References}

Adomako S., Narteh B., Danquah J.K., Analoui F., 2016, Entrepreneurial orientation in dynamic environments: The moderating role of extra-organizational advice, "International Journal of Entrepreneurial Behavior \& Research”, vol. 22 (5), pp. 616-642, DOI: 10.1108/IJEBR-12-2015-0320.

Blackburn R.A., Hart M., Wainwright T., 2013, Small business performance: business, strategy and owner-manager characteristics, "Journal of Small Business and Enterprise Development”, vol. 20(1), pp. 8-27, DOI: 10.1108/14626001311298394.

Carey J.P., 2015, External accountants' business advice and SME performance, "Pacific Accounting Review”, vol. 27(2), pp. 166-188, DOI: 10.1108/PAR-04-2013-0020. Daspit J.J., D'Souza D.E., 2013, Understanding the Multi-Dimensional Nature of Absorptive Capacity, "Journal of Managerial Issues", vol. 25(3), pp. 299-316. 
Duchek S., 2015, Designing absorptive capacity? An analysis of knowledge absorption practices in German high-tech firms, "International Journal of Innovation Management", vol. 19(4), pp. 1-22, DOI: 10.1142/S1363919615500449.

Dyer L.M, Ross Ch.A., 2007, Advising the Small Business Client, "International Small Business Journal”, vol. 25(2), pp. 130-151, DOI: 10.1177/0266242607074517.

Engelen A., Kube H., Schmidt S., Flatten T.Ch., 2014, Entrepreneurial orientation in turbulent environments: The moderating role of absorptive capacity, "Research Policy", vol. 43(8), pp. 1353-1369, DOI: 10.1016/j.respol.2014.03.002.

Głodek P., Łobacz K., Stawasz E., Niedzielski P., 2016, Utilisation of business advice in small innovative firms - the role of trust and tacit knowledge, "Entrepreneurial Business and Economics Review", vol. 4(2), pp. 117-138, DOI: 10.15678/EBER.2016. 040210.

Gooderham P., Tobiassen A.E., Doving E., Nordhaug O., 2004, Accountants as Sources of Business Advice for Small Firms, "International Small Business Journal", vol. 22(1), pp. 5-22, DOI: $10.1177 / 0266242604039478$.

Grabowski W., Stawasz E., 2017, The role of business consulting in creating knowledge and formulating a strategy of development in polish micro-enterprises, "Journal for East European Management Studies (JEEMS)", vol. 22(3), pp. 374-396, DOI: 10.5771/ 0949-6181-2017-3-374.

Hutchinson, V., Quintas P., 2008, Do SMEs do Knowledge Management? Or Simply Manage what they Know?, "International Small Business Journal", vol. 26(2), pp. 131154, DOI: $10.1177 / 0266242607086571$.

Kang K.H., Kang J., 2009, How do firms source external knowledge for innovation? Analysing effects of different knowledge sourcing methods, "International Journal of Innovation Management”, vol. 13(1), pp. 1-17, DOI: 10.1142/S1363919609002194.

Krzakiewicz K., Cyfert Sz., 2018, Strategiczne aspekty dynamicznych zdolności replikacii i imitacii wiedsyy, „Przegląd Organizacij”, nr 3(938), s. 5-12, DOI: 10.33141/po. 2018.03.01.

Lagunes P., Soto A., Zuniga S., 2016, Model for Determining the Absorption Capacity of SMES in the Manufacturing Sector, "European Scientific Journal", vol. 12(34), pp. 322-337, DOI: 10.19044/esj.2016.v12n34p322.

Lisowska R., 2015, External Determinants of the Development of Small and Medium-Sized Enterprises - Empirical Analysis, "Journal of Entrepreneurship, Management and Innovation (JEMI)", vol. 11(4), pp. 115-138, DOI: 10.7341/20151145.

Matejun M., 2015, Absorpcja wsparcia w zarzadzaniu rozwojem mikero, matych $i$ średnich przedsiębiorstw - podejście strategiczne, "Zeszyty Naukowe Politechniki Lódzkiej”, nr 1194.

Mazzarol T., 2011, Entrepreneurship and Innovation. Readings and Cases, 2nd edition, Tilde University Press. 
Mole K., Baldock R., North D., 2013, Who Takes Advice? Firm Size Threshold, Competence, Concerns and Informality in a Contingency Approach, "ERC Research Paper", vol. 9, pp. 1-38.

Patterson W., Ambrosini V., 2015, Configuring absorptive capacity as a key process for research intensive firms, “Technovation”, vol. 36-37, pp. 77-89, DOI: 10.1016/j.technovation. 2014.10.003.

Sciascia S., D’Oria L., Bruni M., Larraneta B., 2014, Entrepreneurial Orientation in lowand medium-tech industries: The need for Absorptive Capacity to increase performance, "European Management Journal", vol. 32, pp. 761-769, DOI: 10.1016/j.emj. 2013.12.007.

Stawasz E., Głodek P., Łobacz K., Niedzielski P., 2018, Kształtowanie konkurencyjności małej firmy. Rola doradztwa biznesowego, Wydawnictwo Uniwersytetu Lódzkiego, Łódź.

Teece D.J., 2014, The Foundations of Enterprise Performance: Dynamic and Ordinary Capabilities in an (Economic) Theory of Firms, "The Academy of Management Perspectives", vol. 28(4), pp. 328-352.

Yusoff N.H., Yaacob R., Ibrahim D., 2010, Business Advisory: A Study on Selected Microsized SMEs in Kelantan, Malaysia, "International Journal of Marketing Studies", vol. 2(2), pp. 245-257, DOI:10.5539/ijms.v2n2p245.

Zahra S.A., George G., 2002, Absorptive capacity: a review, reconceptualization, and extension, "Academy of Management Review", vol. 27(2), pp. 185-203, DOI: 10.2307/ 4134351.

Zou T., Ertug G., George G., 2018, The capacity to innovate: a meta-analysis of absorptive capacity, "Innovation: Organization \& Management", vol. 20(2), pp. 87-121, DOI: 10.1080/14479338.2018.1428105. 